Article

\title{
Participatory Land Administration on Customary Lands: A Practical VGI Experiment in Nanton, Ghana
}

\author{
Kwabena Asiama ${ }^{1, *}$, Rohan Bennett ${ }^{2}$ and Jaap Zevenbergen 1 \\ 1 Faculty of Geo-Information Science and Earth Observation (ITC), University of Twente, \\ 7500AE Enschede, The Netherlands; j.a.zevenbergen@utwente.nl \\ 2 Swinburne Business School, Swinburne University of Technology, Melbourne, Victoria 3122, Australia; \\ rohanbennett@swin.edu.au \\ * Correspondence: k.o.asiama@utwente.nl; Tel.: +31-53-489-6183
}

Received: 16 May 2017; Accepted: 19 June 2017; Published: 22 June 2017

\begin{abstract}
Land information is one of the basic requirements for land management activities such as land consolidation. However, the dearth of land information on customary lands limits the development and application of land consolidation. This paper presents and discusses the results of an experiment carried out to test the potential of participatory land administration applied on customary lands in support of land consolidation. A brief overview of the evolution of crowdsourced, voluntary, and participatory approaches is provided alongside newly related insights into neogeography and neo-cadastre, and fit-for-purpose and pro-poor land administration. The concept of participatory land administration is then developed in this context. The area of the experiment is in Northern Ghana where the process was developed together with the local farming community. The study involved collecting land information relating to farms over a two-week period, using a mobile app and a satellite image, based on participatory land administration. The results show that Participatory Land Administration can potentially support land consolidation, though further investigation is needed on how it can be integrated into the formal land registration system, into an actual land consolidation project.
\end{abstract}

Keywords: land administration; crowdsourcing; participation; VGI; land consolidation

\section{Introduction}

Land consolidation is described as a land management activity that involves all the procedures for exchanging, rearranging, realigning, and expanding farm parcels in rural areas with the goal of increasing food productivity. Responsible land consolidation uses approaches that continuously align the technical and administrative requirements, and the internal processes of land consolidation to the dynamic local societal demands, economic conditions, cultural and legal requirements [1]. Although the success of land consolidation is dependent, among other things, on the economic and ecological improvements for the land and the people, one of the basic requirements of land consolidation is information related to the ownership, use, and value of the land [2,3]. The collection, maintenance, and dissemination of land information is described here as land administration [4]. This paper focuses on the collection of land information to support land consolidation. The dearth of land information on Sub-Saharan Africa's rural customary lands has been shown to be one of the militating factors to undertaking land consolidation in the area [5]. This paper presents an experiment into a proposed approach to land administration on customary lands to support responsible land consolidation.

Over the past two decades, observations and experiences in land administration have shown that less than $30 \%$ of the world's countries have a complete land administration system capable of supporting the design and implementation of land management activities such as land consolidation [6,7]. Numerous thrusts into so called conventional western-style titling programmes have not met expectations. This is 
mostly because first, their pace is very slow in relation to the urgency of the results. Secondly, they have been too expensive, leaving them out of the reach of most citizens. Thirdly, these approaches have largely failed to integrate all forms of land tenure arrangements, especially secondary and customary land rights. The outcome is that parts of the community are left vulnerable to land grabs, contentious land disputes, limited investment in land, and increase in food insecurity. In response, calls for pro-poor and fit-for-purpose approaches to land administration have emerged $[7,8]$. These approaches, that seek to adapt local needs and circumstances in tandem with legitimate and acceptable social, cultural, and institutional practices, are described by de Vries et al. [9] as responsible approaches.

Advances in responsible approaches usually consider new ways through which different forms of legitimate land rights can be recorded and documented on one hand; and on the other hand, explore how emerging and cutting edge technologies in geospatial sciences offer faster and cheaper options for spatial data collection. New insights into documenting all forms of land rights have been made by the continuum of land rights by the GLTN [10], and several studies in customary and informal land rights $[6,11,12]$. On the part of spatial data collection, emerging and cutting edge technologies have advanced new approaches to land administration in the form of crowdsourcing, voluntary geographic information (VGI), and neo-cadastres. These technologies include the use of old map documents, high resolution satellite images (HRSI), tools based on Global Navigation Satellite System (GNSS), Unmanned Aerial Vehicles (UAVs) as well as smart technologies such as Automatic Feature Extraction (AFE) of cadastral boundaries [13-16]. These approaches that seek to involve the grassroots in land administration processes further seek to incorporate the societal goals of land administration, the structure of the society, and bring down costs. However these have still not been placed in the societal context, but rather look, among others, at aspects of VGI in applying it to land administration [17], the motivations of contributors [13,18], the ability of the local people to use the technologies [19]. The fundamental reason for these land recordation processes has been land tenure security $[7,11]$. These responsible approaches do not work in isolation, but thrive within a societal context driven by needs other than tenure security such as food security, supporting a land market, levying of taxes, and nature conservation [20]. These, though linked, present different purposes for undertaking land administration. There is therefore a gap in knowledge on how to shape the emerging approaches to land administration to fit into each peculiar societal context and goal, in this case to support land consolidation for food security. This requires the active involvement of the local community in land administration. This is what is termed here as Participatory Land Administration [21]. As previous innovative approaches to land administration focus mainly on securing land tenure, this paper aims at testing an approach to land administration that is capable of supporting food security-stemming from land tenure security - as a social goal. As such, the paper presents an experiment undertaken in Northern Ghana to test how an approach to participatory land administration fits into customary lands to support responsible land consolidation.

\section{Participatory Land Administration: A Theoretical Background}

Participatory land administration is a construct that seeks to contribute to responsible, fit for purpose, and pro-poor approaches to land administration $[8,9,21,22]$. Traditional land administration approaches have been deeply rooted in western approaches and views on land management based on the state's responsibility to collect and manage land information. These have however ended up failing most of the population, especially in developing countries, as societal and cultural considerations are ignored in favour of complex legal and professional standards.

\subsection{From Voluntary Geographic Information to Participatory Land Administration}

The participatory element adds to emerging approaches that challenge traditional land administration approaches. Participation in some circles is considered as a source of power [23], for others it is simply the ability to contribute [24], or a multi-way set of interactions among citizens and other players to produce an outcome [25,26]. Smith [24] considers participation as a stepping stone 
to enhance effectiveness of outcomes, resolve conflicts, enhance public knowledge and understanding, and establish legitimacy and trust. Participation in geo-spatial science stems from the increasing need for local knowledge in a field that has for many years been dominated by professionals, who carried out their tasks per strict standards and quality assurance specifications. This brought about a new approach to mapping_Participatory Geographic Information Science (PGIS) or P-Mapping, involving citizens depicting the features of their environment on the ground, on paper or on satellite imagery with the help of professionals who guide the standards of the entries. The technological innovations in the 21st century expanded the direct involvement of local people to include several other location-based services mostly due to Geo-Spatial Web 2.0-a collection of online location-enabled services and infrastructure $[27,28]$. This brought about a new vista for PGIS known as Voluntary Geographic Information (VGI) - the collecting and editing of digital spatial data by people responding to an open call, with little or no formal qualifications, willing to share their spatial knowledge and information [29-31]. Although VGI and PGIS share the common aim of involving local people, Fast and Rinner [32] and Song and Sun [33] differentiate between the two, with PGIS being traditionally established and controlled by someone with the skills and knowledge in organizing and presenting spatial information with imposed constraints. The basis of VGI is rooted in neogeography and crowdsourcing. Neogeography, on one hand, is the way people represent portions of the earth surface in their own way, alongside or in the manner of professional geography, making it personal, expressive, and although not reaching professional standards, does not render it of no use to geo-sciences [34,35]. Crowdsourcing, on the other hand, is seen as the process of harnessing the diverse potential of large groups of ordinary people in the collection and aggregation of data [36]. The basis of crowdsourcing is a grassroots-based approach that is often initiated to challenge formal approaches and offset its constraints and inadequacies. Many therefore view VGI as having a higher participation than PGIS, as the public has a greater control over the process. However, VGI for land administration is still a debated issue.

The success of crowdsourcing geo-spatial information in disaster management [37], identifying land use patterns [38], road map production [39,40], among others, has led to exploration on how crowdsourcing can be applied to land administration. In an attempt to improve upon traditional land administration processes, initial studies into crowdsourced land administration looked at an approach of citizens directly capturing, maintaining, and disseminating information on land rights [41,42]. However later studies stressed on the importance of reliability and accuracy of land information as an aspect of public administration, as opposed to the initiatives into crowdsourcing such as openstreetmaps and wikimapia [43]. To maintain the reliability of the information, some suggest the use of local Trusted Intermediaries (TI) [44,45]. Furthermore, a pure crowdsourced approach to land administration which will rely on the strong relationships within local communities, is likely to produce a record of land rights that are outside the existing formal systems, limiting the ability of the people it serves to take advantage of some of its benefits [46].

Later contributions to the subject take a hindsight cue from Turner [35] to look theoretically at how communities outside the state based land administration system record and maintain their land rights. De Vries et al. [15] characterizes this as the "Neo-cadastre" - the manner through which land holders and users indicate their land tenure rights and boundaries based on their personal views outside of state-based institutions. The impact of the Neo-cadastre has been largely speculative. Whilst de Vries et al. [15] contend that it will not challenge the traditional land administration systems within the foreseeable future due to its lack of standards, Schaefer \& Schaefer [47] rather indicate the eventual need for the government to accept it when it reaches a critical stage. Neo-cadastre therefore shows the ability of local and indigenous people to devise their own ways of recognizing their land rights, and a new approach of land registration should also take that into consideration. The nature of land administration as a public administration activity, dealing with the management of sensitive information, citizen contribution requires some form of regulation and guidance at varying levels 
as found in PGIS, but not to the standard of traditional land administration. This is what this paper describes as Participatory Land Administration (PLA).

\subsection{Aspects of Participatory Land Administration}

Participatory land administration encompasses four aspects drawn from conventional, responsible, fit for purpose and pro-poor land administration, seeking to create a meeting point for the top-down traditional and bottom-up crowdsourced land administration. These four aspects are the top-down institutional (government and professional) influence, the bottom-up citizen contributions, the push of technological innovation, and the pull of societal needs (Figure 1). Traditional land administration focuses on a top-down approach, with the government authorities and the professionals as the main contributors to land administration using strict standards with high accuracy and high-end equipment regardless of the societal needs and make up. Participatory land administration sits at the nexus of the drivers of technological innovation and approaches to development studies. The drivers of technological innovation in the last few decades have strived to strike a balance between the role of innovations in science and technology on the one hand, and an acknowledgement of a broader set of market features on the other hand [48,49]. The former, known as technological-push, advocates that innovation should be dictated by the technologies available, with little consultation with the end beneficiaries. The later acknowledges a broader set of market features including the needs and characteristics of the end beneficiaries that affect the performance of the technology known as the demand or societal-pull. This combination of the technological-push and societal-pull is deemed necessary as the two interact. It is seen that the societal-pull policies also aid in inducing and directing innovation to be closely aligned with the societal needs. However, studies into this area have mostly focused on leveraging this relationship to commercialize successful innovations, rather than the harnessing of emerging technologies to ease the approaches to services, such as land administration, in the direction of the clients it serves [50]. The new approaches to development studies, also a construct of the last few decades, is in response to local and regional development policies responses to peculiar territorial challenges [51]. These approaches have questioned the sustained ability of the conventional top-down approaches to policy development. These new approaches therefore merge the macro and micro economic theories behind top-down approaches led by the government and professionals with meso-local concepts that inform bottom-up development strategies from the local people. Ghawana et al. [50] describes how the harnessing of technology-push and demand-pull approaches can support research and development in land administration research and development, making it more visible to key stakeholders and enhancing its applicability by making it more innovation oriented. However, they fall short of incorporating the stakeholders in their model. Rahmatizadeh [17] also conceptualizes the use of VGI in land administration, focusing on the top-down and bottom-up interaction of the actors and legal restrictions.

Participatory land administration encompasses the above approaches to innovative land administration and relies on the consideration of both the interaction of the key actors in the top-down-bottom-up approach for social inclusion (Figure 1-vertical aspect), as well as the technological-push and societal-pull drivers to innovation (Figure 1-horizontal aspect). In this regard, participatory land administration's aspects are the institutional influence (comprising the top-down influence of government and professionals and the bottom-up contribution of the citizens), the push of technological innovations, and the pull of the society's needs that form the basis for undertaking land administration. 


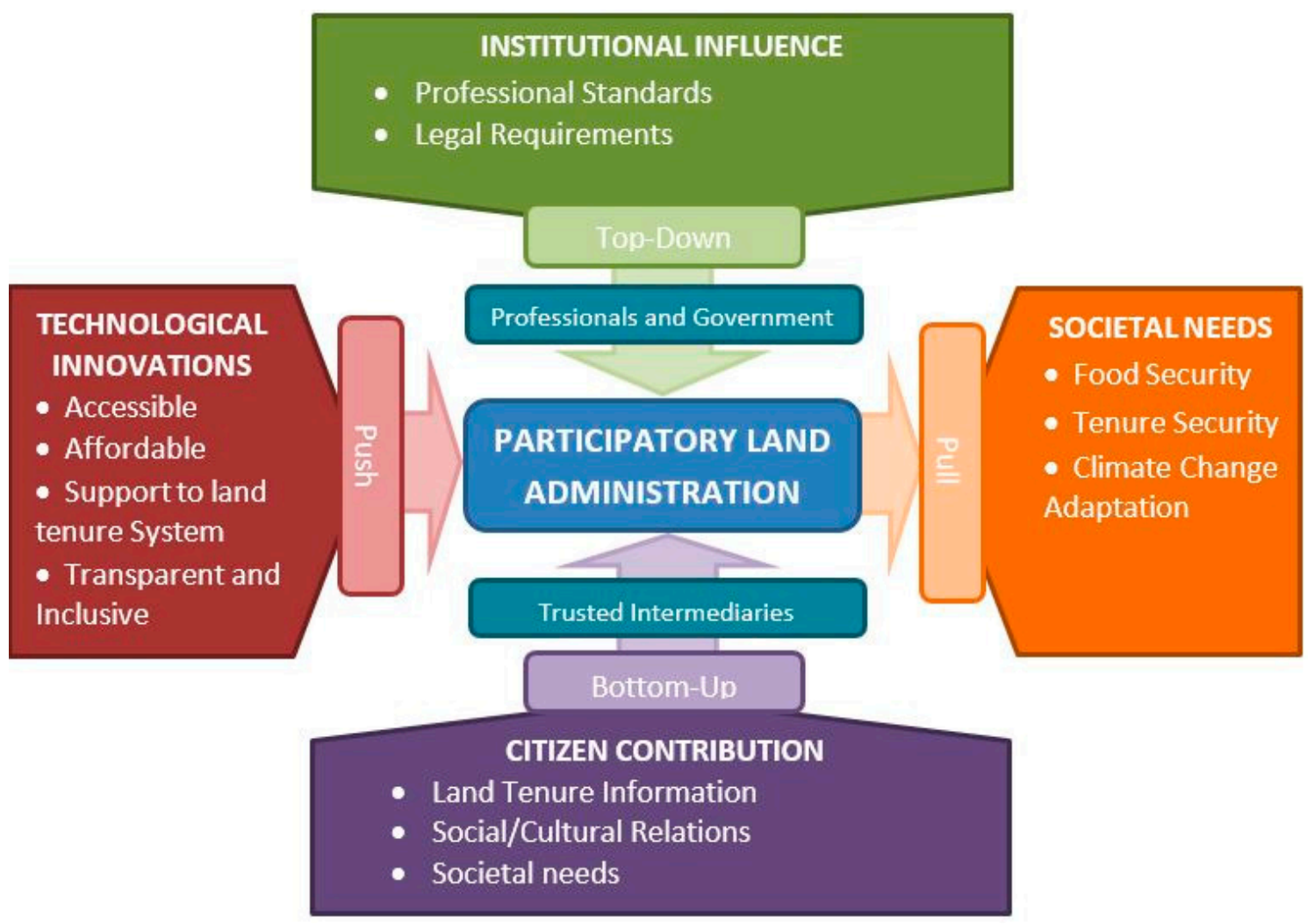

Figure 1. Structure of Participatory Land Administration (The Societal Need considered in this paper is Food Security).

- Institutional Influence of Professional Standards and Legal Requirements:

Conventional land administration is dominated by high professional standards and strict legal requirements that have long been established, the key actors being the professionals and government actors. The acceptance of this approach has been rooted in the trust lent to it by its proprietors as well as its sustainability. Although, as this strict approach has largely failed in $70 \%$ of the world [52], and a citizen-led approach has been advocated by innovative approaches, PLA acknowledges the need for significant level of standards and regulations needed in the land administration process for the land rights captured to be seamlessly integrated in the formal system.

\section{- Citizen Contribution:}

This acknowledges the potential for the involvement of the local people and other relevant stakeholders in land administration activities, through carefully negotiated arrangements that ensures clear roles, rights, and responsibilities of the involved parties, and not just by way of consultation in the actual implementation. It allows process to take the local people's complete land tenure arrangements, social cultural relations, and peculiar societal needs into account. This also allows for the local people to feel a sense of ownership to the land information to enable them to build trust in it. By allowing for some oversight by local Trusted Intermediaries, information that are contributed are verified and substantiated. Trusted Intermediaries are key members of the communities who are deemed knowledgeable by the community members of the local traditions and land ownership and can aid in substantiating land rights claims in the area.

A partnership is therefore created to balance the institutional influence of the government and professional's top-down approach, as well as the emerging bottom-up approaches that is empowering citizens. 
- Societal Needs and Considerations:

The pull of societal needs is can be derived from the partnership relationship to determine the land administration goals. There is a need to identify the societal needs of the communities that the land administration seeks to serve, which will then judge the amount and depth of land information needed. These societal needs include, among others, land tenure security, taxation, support to a land market, food security, and climate change adaptation [20]. These will judge the amount of the information needed.

- Technological Innovations:

The push of technological innovations to aid land administration activities stemming from the societal needs and the balance that is achieved between the government and the other stakeholders, needs to be pro-poor [7]. That is, it must be accessible and affordable to the local people, it should can support the local land tenure system, transparent and inclusive of all the people involved.

\section{The Experiment}

The experiment seeks to test the suitability of Participatory Land Administration on Ghana's rural customary lands as described in the previous sections. Current innovative approaches to customary land administration in Ghana are first explored. This is followed by an overview and justification of the selected area of interest for the experiment. The practical process of the experiment is then described.

\subsection{Innovative Approaches to Customary Land Administration in Ghana}

Ghana has a dual system of land registration, the deed and the title registration. However, there are attempts to phase out the former in favour of the later. Land title registration (LTR) in Ghana started with the aim of a systematic registration of common law and customary interests, namely the allodial interest, the common law freehold, the customary freehold, leasehold interests, and customary tenancy [53]. However, the formulated procedures solely provide procedures for leasehold interests. This is because the roll out of the law focused on the urban areas, where land registration was deemed to be an urgent need. Leasehold interest dominates the land tenure system of the urban areas. Since the inception of the LTR, 30,000 parcels in Ghana have been registered [54-56]. This has led to several attempts at innovative initiatives to aid the land registration process. Notable and most recent among these are the Millennium Development Authority's Systematic Titling, the Paralegal Titling Project by Corporate Initiative Development Group (CIDG), Medeem Proprietary ParcelCert, LandMapp Initiative, and the Community-based Land Survey Tool by Land Resource Management Centre (LMRC). The following is a brief overview of these initiatives in Ghana.

The Millennium Development Authority's Systematic titling was started with the aim of improving tenure security and facilitating access to land for commercial crops. In a comprehensive roll out of the process using modern high accuracy GNSS and database systems, the project was able to register 270 parcels at costs ranging from EUR200 to EUR270 per parcel [57]. The Paralegal Titling project was undertaken from 2007 to 2009 by a group of companies led by the Corporate Initiatives group to issue para-legal titles, that are capable of being easily converted into formal titles. This initiative, built on the open title concept, also required the use of large field teams and high accuracy GNSS equipment in order to meet the Lands Commission's requirements [58]. This initiative also focused on urban lands and attempted to only register leaseholds. LandMapp initiative has also made in roads with large-scale commercial cash crop farmers, providing land documents that are meant to ensure tenure security. This is however only available for ownership of leasehold and not customary interests $[59,60]$. The Community-based Land Survey Tool, was developed by LMRC, an indigenous Ghanaian research and development institute, as an innovative tool to support tenure security in cocoa growing areas of the country [61]. 
It is shown firstly, all five recent innovative approaches in Ghana were largely led by the developing agency, with little input by the local structures and farmers involved. Secondly, these initiatives focused largely on fitting in the land title registration. Therefore, they result in either a focus on leasehold interest, or an attempt to convert customary interests into common law interests. This will allow the land information collect to be easily integrated into the land title register which has no provision for customary interests. Thirdly, the current innovative approaches rather place more emphasis on land tenure security without making allowances for other land management activities such as land consolidation. To develop an appropriate land administration system for customary lands, the principles of pro-poor and fit-for-purpose land administration must be followed. These are identified by Enemark et al. [8] and Zevenbergen et al. [7] as flexibility, participatory, affordability, support to land tenure system, and transparent among others. Furthermore, for the land administration system to be appropriate for land consolidation, information pertaining to topography, soil types, water distribution and the types of crops grown which are relevant to land consolidation should be included. Following the shortfalls of the current innovative approaches identified in Ghana to support land consolidation, there is the need for new approaches that place more focus on the target community, allowing them to undertake the process on their own, as well as incorporating the necessary information. This will allow for a better assessment of how the local community can sustain the system on their own.

\subsection{The Area of Interest}

The area of interest is located within the Nanton Traditional Area of the traditional Kingdom of Dagbon in the Northern Region of Ghana. All lands in the kingdom are held under customary land tenure system, with the Ya-Na (the King) managing the lands at the top of the land holding hierarchy. The lands then devolve to the traditional areas, one of which is Nanton (with the Nanton-Na as the Chief), then down to the village skins. Nanton also falls under the Savelugu-Nanton local government district. The vegetation in the area is largely guinea savannah with tall grasses and few trees (mainly shea, acacia, baobab and mango), dotting the entire landscape. The area experiences a single rainfall season (April-October) accompanied by a long dry season (November-March) that brings in the harmattan winds. The inhabitants are mainly agro-pastoralists engaged in food crops and livestock production.

Land registration in the area takes the form of deed registration as the area has not yet been declared a Land Title Registration (LTR) area. This means little is done by way of the survey and mapping of parcel boundaries when registering land. This notwithstanding, the Nanton-Na (Chief of Nanton) has set up a Customary Land Secretariat (CLS) to assist with the management of the lands. However, since the LTR has no procedures for registering the customary interests, the CLS only focuses on the leasehold which are mostly held in residential properties, leaving out farm parcels which are mostly held in customary interests [5].

Nanton is chosen to be the site of the experiment for three reasons. The first is the existing customary land tenure system in the area, together with the existing CLS that provides a private land management body that comprises local people. The second is the vegetation cover of the area, guinea savannah, together with the climate of the area that reduces the incidence of multipath errors and cloudy satellite imagery. Thirdly, agriculture is the main vocation in the area, with many small-scale farmers with small and scattered parcels, with a need for land consolidation [62]. The farms on the Eastern part of the Nanton Village were mapped by the farmers, and family heads, with the assistance of the Trusted Intermediaries (TI) (Figure 2). Over a period of ten days, 230 farms covering an area of 3 square kilometres were mapped, with their accompanying interests recorded. This was done in a Living Lab-styled arrangement by the 85 farmers from 18 families who hold those farms, two Trusted Intermediaries and the Traditional Authorities. 

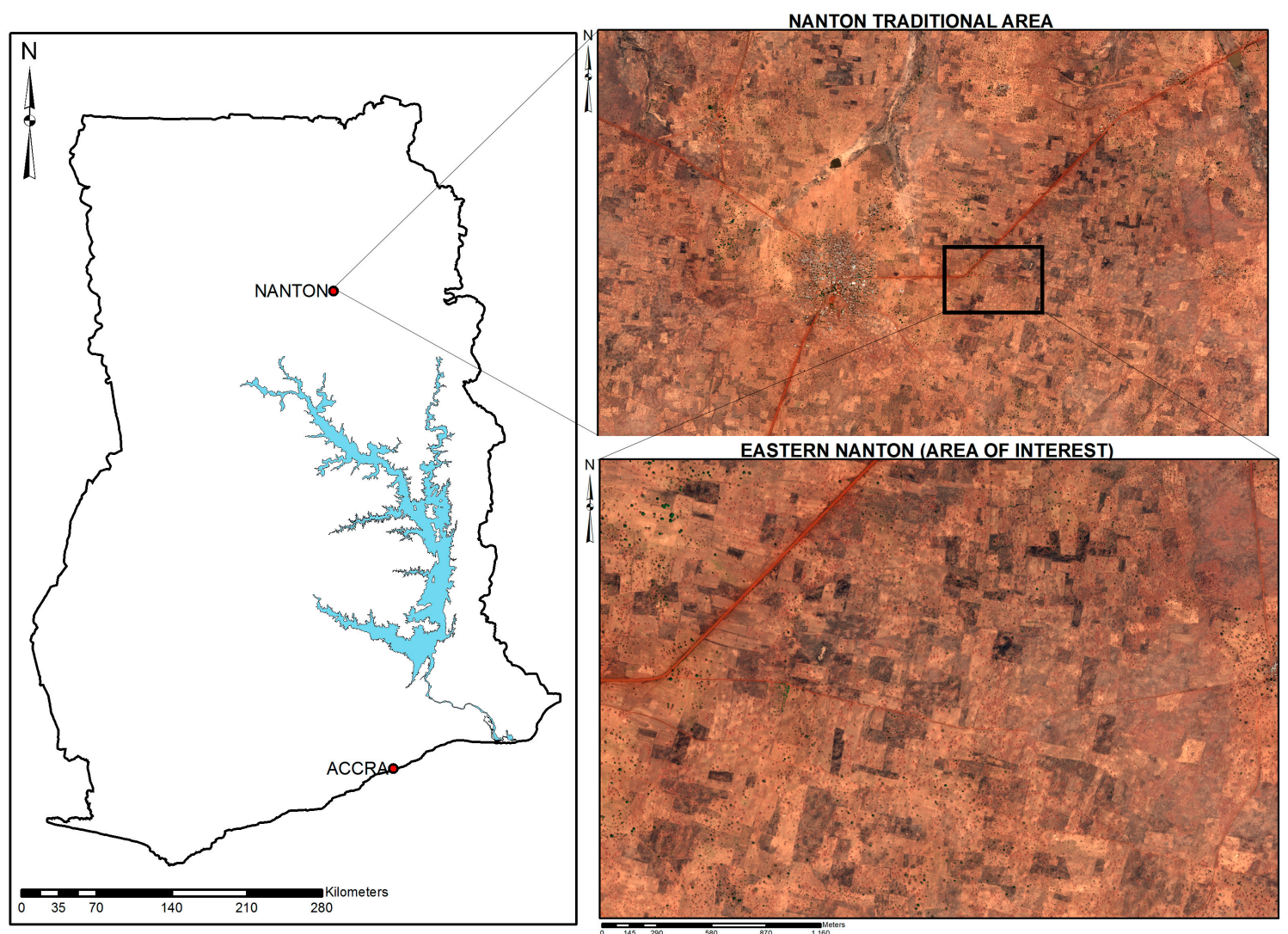

Figure 2. Map showing the area of interest in the Nanton Traditional Area and Ghana (Satellite image courtesy of DigitalGlobe Foundation).

\subsection{The Practical Process}

A living lab approach is adopted for the experiment. A Living Lab is a combined lab/household system, analysing existing product service systems as well as technical and socioeconomic influences focused on the social needs of people, aimed at the development of integrated technical and social innovations and simultaneously promoting the conditions of sustainable development (highest resource efficiency, highest user orientation, etc.) [63-65]. It is based on two main concepts-first is the involvement of users early in the innovative process, and the second is experimentation in real-world settings, aimed at integrating the social structure and governance, as well as user participation in the innovative process. The living lab approach encourages trust, allows access to adequate knowledge regarding the problem environment, and gives the users a sense of ownership of the product. The subjects of the experiment were identified first with the assistance of the Traditional Authority (the Nanton-Na and the family heads in the area) and the leaders of the Farmers' Association of the area. An interview was first conducted with land registration officers and land surveyors of the Lands Commission of Ghana to ascertain the ascertain statutory land registration and survey process. The researcher together with the two groups, identified the land tenure arrangement in the form found by Asiama et al. [5]. The Traditional Authority, the Farmers' Association and the researcher then used to develop the process of the mapping and recording of the land rights, with the researcher applying the inputs from the interview with the Lands Commission to align the developed process to the statutory process, and the former groups providing inputs on the local land administration.

Two technologies were adopted for the experiment-a smartphone app and satellite imagery. These technologies were first tested in a pilot undertaken in January 2016 to ascertain their ability. The smartphone app used was Esri's Collector for ArcGIS, which allows for a very effective and efficient collection of spatial data. The data collection method was based on polygons rather than 
boundaries. The polygons are associated with information relation to the farm parcel relevant to land consolidation and land tenure such as the names of the land right holders, from the allodial title (the skin involved), through the sub-allodial (the family holder), the customary freeholder or the tenant (the individual) if any; the crops grown on the farm, the seasons the farm is used, and the nature of the soil. This information is provided by the farmers, affirmed by the TIs, added as attributes, and regarded as the ground truth. The data collected can be viewed and processed in a cloud-based geographic information system, or alternatively downloaded for areas with limited internet connectivity. The app can also be used in combination with a GNSS receiver such as the Trimble R1 to achieve a centimetre accuracy through Bluetooth connection. However, since this experiment aimed at using materials and equipment within the means of the subjects, a low-priced 3G smartphone commonly found on the Ghanaian market was used. The mobile app has the ability to estimate the accuracy of the data collected. The second technology was satellite images. Here a February 2016 GeoEye- 1 satellite image of the area of interest was freely acquired from DigitalGlobe Foundation, and printed at a scale of 1:4000, which is within the range of scales recommended by Byanmugisha et al. [66] for mapping rural agricultural land parcels with medium density. A February 2016 GeoEye-1 satellite image at the scale of 1:2000 (a scale at which rural houses are distinguishable [67]) of the Nanton village was first presented to the farmers and the trusted intermediaries to train them by identifying the key features in the village such the chief's palace, the school, the village square and their own houses. The farmers and the trusted intermediaries then gathered around the satellite image of the farms and the farmers identified their farms with red pens. When there was concurrence by the neighbours and the trusted intermediaries, the TI's marked the boundaries in black, signifying a final boundary (Figure 3).

Two methods are adopted in order to be able to compare the effectiveness of the two. Other innovative approaches have taken place in areas with existing cadastral data, giving an opportunity to assess the approach against existing information. With no existing information in this area of interest, having a second approach aids with the assessment of the both innovative approaches. The satellite imagery, on the one hand, is a relatively accepted approach having been successfully used in Rwanda, Ethiopia, and Kenya, and is recommended as a fit for purpose approach for land administration $[8,68,69]$. On the other hand, the mobile app is a relatively new approach, having been tested in other parts of the world but not on customary lands $[13,19,70]$.

After the mapping and the recording of the land rights, a focus group discussion was conducted with eight farmers selected from among the farmers who were part of the mapping process and trusted intermediaries at the village centre. The focus group discussion sought to ascertain their views about the process, the technology, as well as whether they will be able to replicate the process on their own.

The experiment was then assessed using the elements of fit for purpose land administration (Table 1) [8]. The fit for purpose land administration elements were selected from among a pool of other assessment frameworks such as the ISO 19157 Geographic Information—Data Quality standards and the aspects of responsible land administration [9]. The ISO 19157 is limited to an assessment of the quality of spatial data without the accompanying land information. Responsible land administration also concerns itself with the macro level assessment of land administration. Both frameworks are therefore unsuitable for assess this experiment. Four elements of fit for purpose land administration were selected to assess the approach as these were considered relevant to the initial experiment. The other three elements were found to be outside the scope of this work. These elements, adapted from FIG's Fit for Purpose land administration, are participation, affordability, reliability, and attainability. Participation is measured by the percentage of the procedure that involves the direct input and involvement of the local actors, and the ease with which the local actors can adapt to the technology used. The percentage of the procedure is ascertained by outlining the steps in the procedure according to the actors, and determining the number of steps each actor is involved in. Affordability involves the costs involved in the setting up and undertaking of the process vis-à-vis the current conventional and innovative approaches available, as well as the income of the users. This is determined by ascertaining the cost of the materials, equipment, and wages involved in each step. The cost of the process obtained 
here is then compared to the cost of the traditional process and the existing innovative approaches. Reliability of the approach relates to the ability of the approach to accurately represent the ground truth. It is measured by the spatial accuracy of the data, the ability to achieve coverage of the area of interest, the coverage of all land tenure types. The spatial accuracy of the mobile app is obtained from the app itself. With respect to the coverage of all the land tenure types, this is determined by cross-checking from the CLS the rights inherent in the farm parcels to determine whether all the rights have been mapped and recorded. Attainability of the approach refers to the capacity to successfully establish the system without external support within an appropriate timeframe. Attainability is measured by the ability of the people to replicate the process and the duration of the process. This is done by making using only materials and equipment found in the area of interest, and the ability of the local people to use these equipment. The duration is measured by the average amount of time it takes a farmer and a TI to adjudicate and the map the boundaries of a parcel, as well as the number of days (based on 8-hour work day) used to complete the mapping of the area of interest. Table 1 summarises the elements and their indicators.

Table 1. Summary of Assessment Elements and Indicators.

\begin{tabular}{|c|c|}
\hline RELIABILITY & $\begin{array}{l}\text { - The spatial accuracy of the approach. } \\
\text { - The ability to collect all land parcels in the area. } \\
\text { - } \quad \text { The coverage of all land tenure types. }\end{array}$ \\
\hline AFFORDABILITY & - The cost of the Process vs the current processes. \\
\hline PARTICIPATION & $\begin{array}{l}\text { - } \quad \text { Percentage of procedure undertaken by each actor. } \\
\text { - The ease of use of the technology. } \\
\text { - The amount of input of the actors in the process. }\end{array}$ \\
\hline ATTAINABILITY & $\begin{array}{l}\text { - The duration for data collection. } \\
\text { - The ability of the people to replicate the process. }\end{array}$ \\
\hline
\end{tabular}

\section{The Outcome}

This section outlines the results of the experiment in terms of the assessment criteria set out in the previous section in terms of reliability, affordability, participation, and attainability.

\subsection{Reliability}

In the experiment, it was found that both technologies adopted were easy for the farmers to use. The use of the smartphone app enabled the farmers to walk the boundaries of their farms as the boundary was record by the app and automatically uploaded to a cloud-based GIS. The main advantage of this is the reduced possibility of gross errors related to wrongly collected boundary data as the farmers know their farms best. Most of the farmers and the Trusted Intermediaries (TI) were already familiar with the use of smartphones, with most of them owning one themselves. However, the GNSS signal on the smartphones created a disadvantage with respect to the accuracy. The accuracy of the GNSS relies on the strength of the signal which is be influenced by several factors including the vegetation and the buildings in the area, as well as the terrain and atmospheric conditions. The accuracy of the mapping in the experiment ranged from one to five metres, mostly because of the cloud cover. The experiment was undertaken during the rainy season, therefore there was more cloud cover as compared to the dry season when the pilot was undertaken where an accuracy of one to three meters was observed. However, the area of interest being located in a guinea savannah grassland vegetation zone with trees several meters apart meant that vegetation had little effect on the accuracy, in comparison to an attempt by Osei-Tutu et al. [71] to using a mobile app in the rain forest area. With respect to the satellite image, the images were not related to ground control points. Therefore 
the absolute accuracy is up to $10 \mathrm{~m}$ after ortho-rectification. However, ground control points will be needed for the absolute pixel accuracy.

No boundary disputes were witnessed during the experiment with the mobile app. The farmers during the focus group discussion attributed this to the planting of certain deep rooted plants and footpaths that service as boundaries. Not all the farmers were present during the experiment, in which case the Traditional Authority, together with the TI's and the leaders of the Farmers' Union saw it fit that at least two farmers on neighbouring farms were enough to show the boundaries, followed by a verification by the TI (Figure 3). In such situations, all four parties were always in agreement with the identified boundaries. This was however not the case for the mapping on the satellite imagery, where at least $25 \%$ of the parcels identified by the farmers were either not confirmed or altered by the TI's.

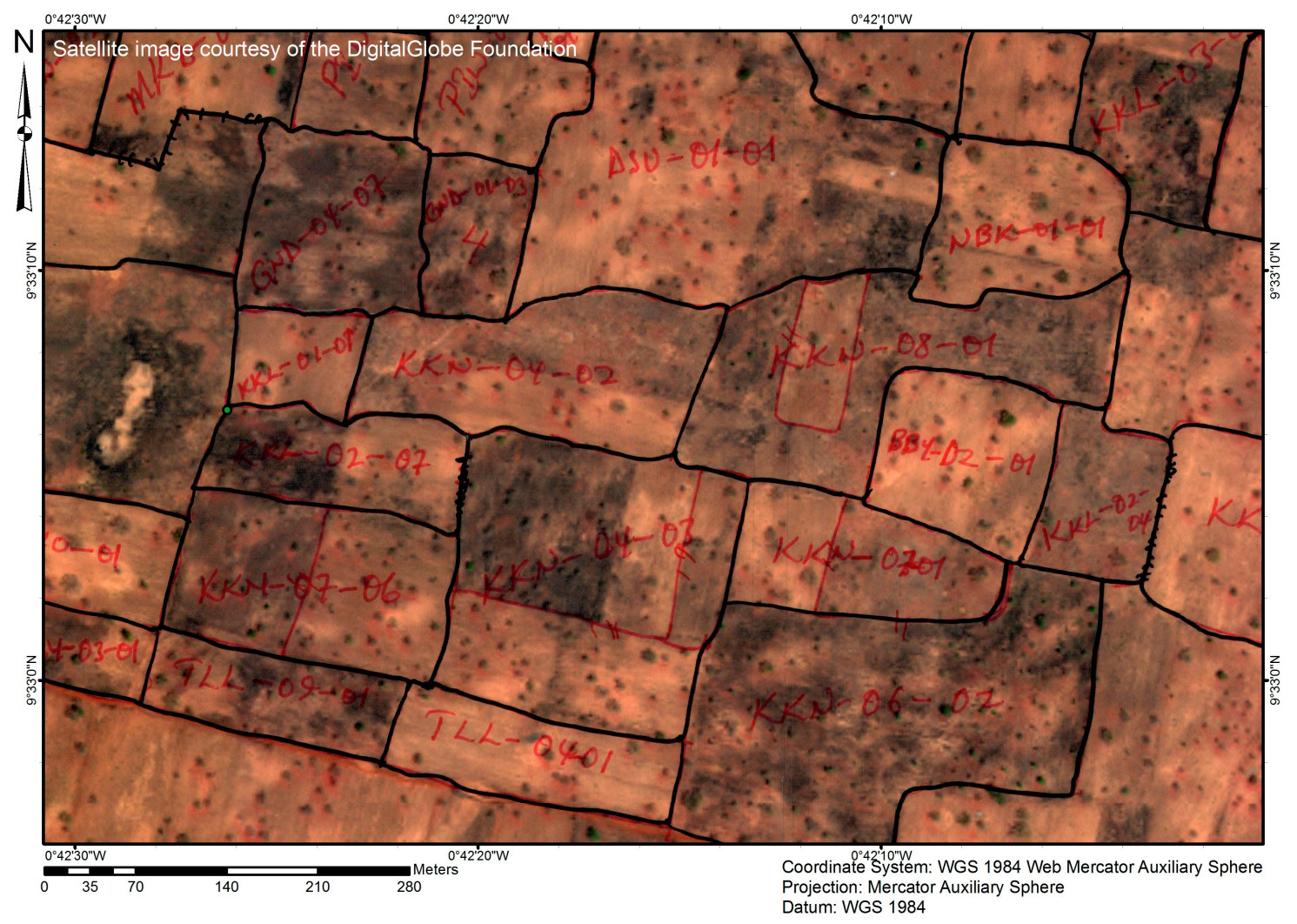

Figure 3. Part of the satellite image from the farm parcel identification showing Red Lines that are parcels identified by farmers and Black lines being parcels verified by the Trusted Intermediaries.

Figure 4 shows a comparison between the farm boundary parcel data collected using the mobile app, and those collected using satellite imagery. It was found that out of the 230 Parcels collected using the mobile app, $62 \%$ were identified on the satellite imagery (Table 2). Though the satellite image has been touted as an effective fit for purpose approach [52,68], but in this case, it does not fulfil the task. This mostly occurred on farms which cultivated the same crop, therefore the similar vegetation cover made it difficult to distinguish the farms. The use of the satellite imagery took some training before the farmers could identify their parcels. When asked how they could identify their parcels, the farmers indicated that once a neighbouring farm was identified, they used the number of trees, changes in vegetation cover, and visible footpaths to define their boundaries. That notwithstanding, all the parcel boundaries that were identified from the satellite image largely corresponded with those collected through the mobile app. The use of the mobile app by walking the boundaries and satellite image had an advantage over the conventional methods used by the licensed and official surveyors as the two methods in the experiment were better suited to capture the irregularly shaped farm parcels because 
the conventional methods take points only at the corner of the parcel. Therefore although the two methods tested are able to maintain the shape and area of the farm parcels collected, the mobile app is better suited for the area as it was able to collect all the farm parcels in the area of interest.

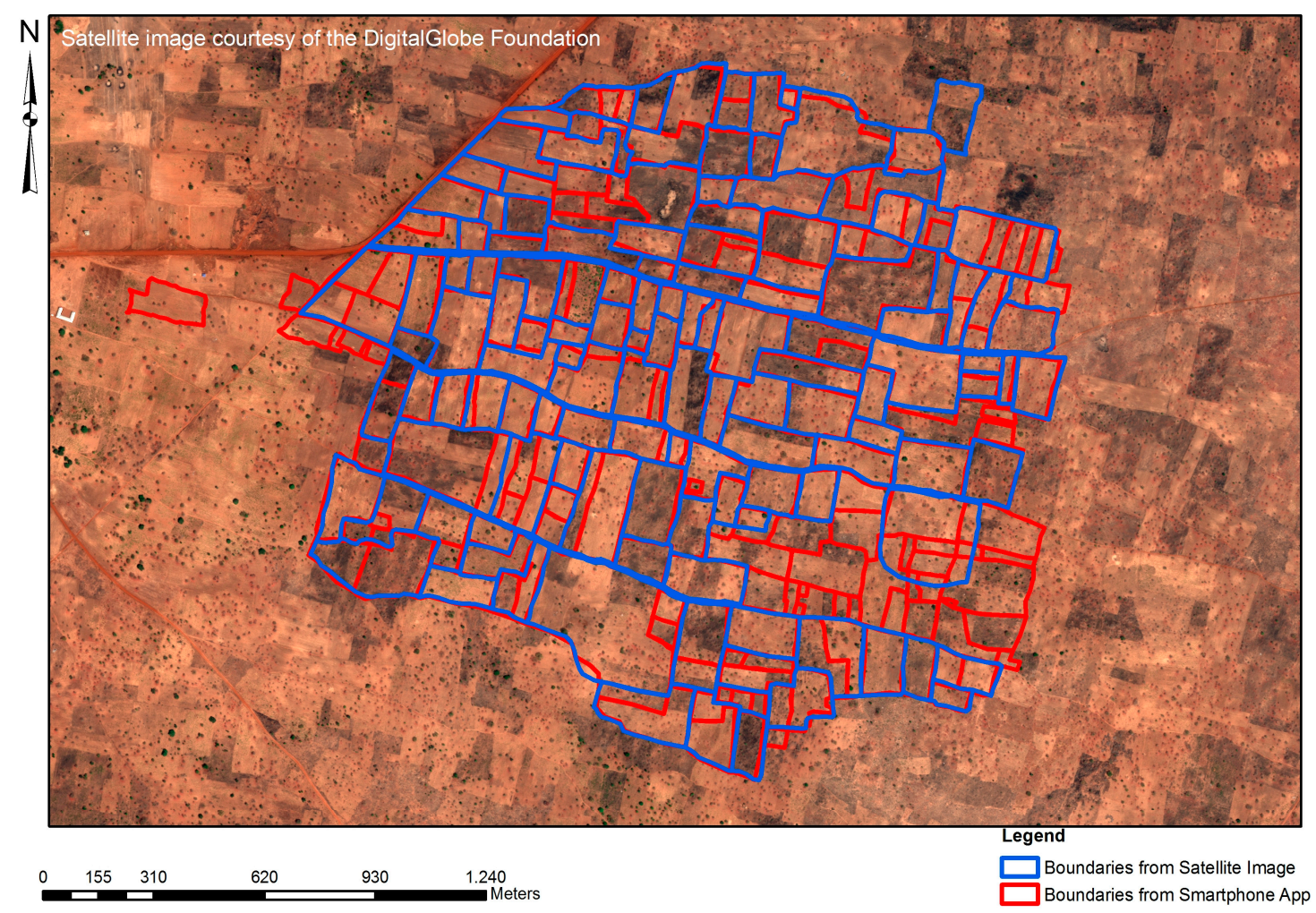

Figure 4. Parcels boundaries collected by Satellite Image (Blue) and Mobile App (Red).

In terms of the ability to capture all the farm land tenure types, the three key land tenure types ascertained in the area, from the interview with the traditional authorities, were the allodial (and sub-allodial) interest, the customary freehold/usufractuary interest, and the customary tenancy, in order of priority. These three interests were adequately captured by the approach, mapped out and recorded. The land tenure types are summarized in Table 2 and shown in Figure 5, with the entire area being held in allodial interest under the Nanton skin, the family lands being held in sub-allodial interest, and the individual parcels (divisions in the family lands) being held in customary interest.

Table 2. Summary of Data Collected.

\begin{tabular}{cc}
\hline Category & Amount \\
Size of the total area of interest & 300 hectares \\
Number of individual farm parcels in area of interest & 230 Parcels \\
Number of individual farm parcels collected by mobile app by participants & 230 Parcels \\
Number of individual farm parcels identifiable on satellite image by participants & 144 Parcels \\
Number of Family Lands (i.e., aggregated collections of parcels) & 29 Farm holdings \\
Area of largest farm parcel & 11.14 hectares \\
Area of smallest farm parcel & 0.07 hectares \\
Average area of farm parcels & 1.29 hectares \\
Standard deviation of farm parcel areas & 1.11 \\
Number of farm parcels held in customary freehold & 220 Parcels \\
Number of farm parcels held in customary tenancy & 12 Parcels \\
\hline
\end{tabular}




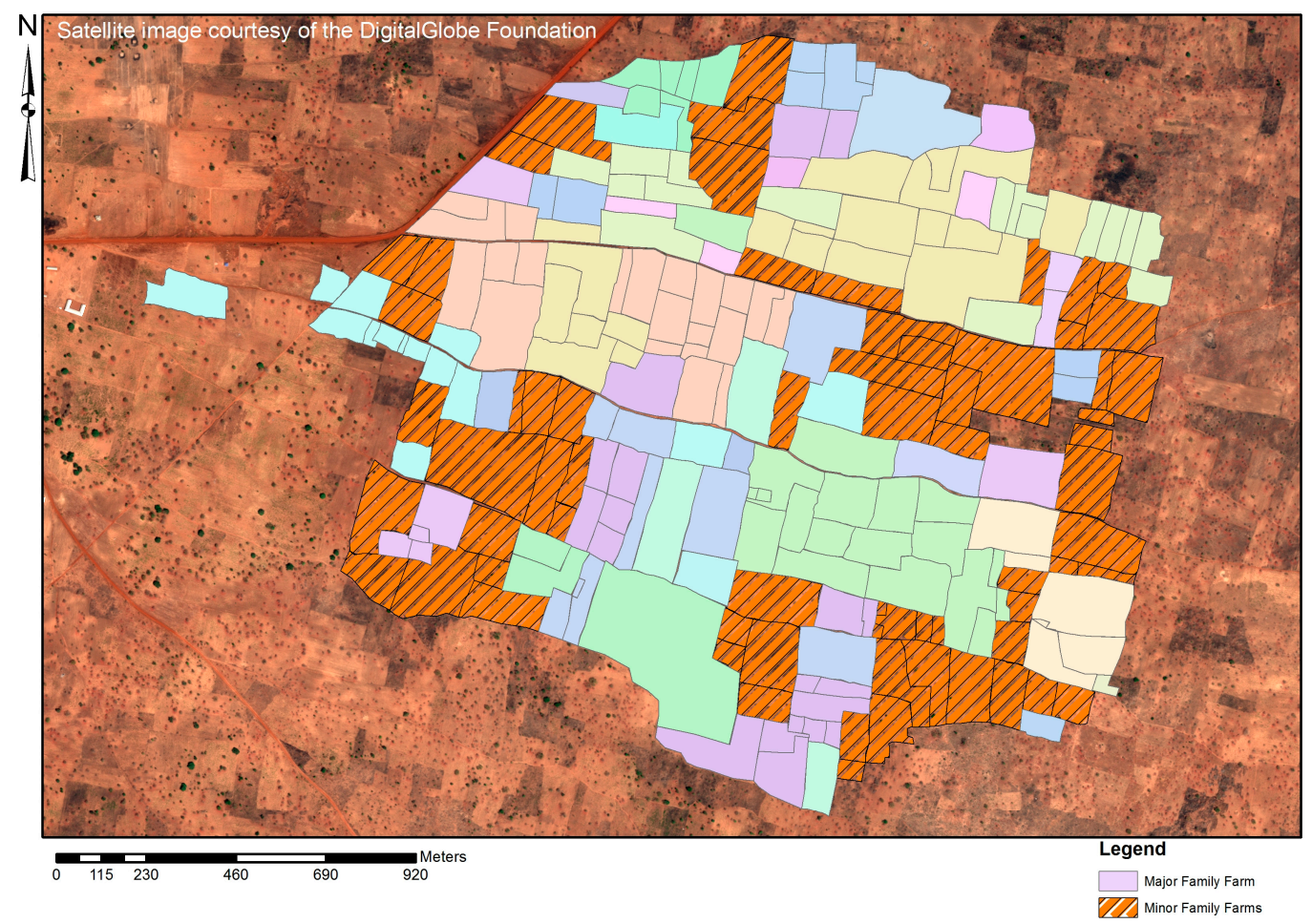

Figure 5. Family Lands in the Area of Interest (Sub-Allodial Interest as family farms and divisions into Customary Freehold as Individual Farms).

\subsection{Affordability}

The mobile app and the satellite imagery were found to be cheaper, more accessible, and easier to use than the current approaches on customary lands. The cost of the mobile app was found to be cheap compared to the cost of surveys by licensed and official surveyors, and the other attempts at pro-poor land administration in Ghana such as Paralegal Titling Project, at least GH 500 (€125) and GHф 200 (€50) respectively per an acre parcel. Per the farmers and the Customary Land Secretariat (CLS), the cost is one of the main reasons why no land survey has taken place in the area. The costing of the approach took into consideration all the costs incurred from the start of the process till the end. However, later costing for the scaling up of the approach will be served better by other standard methods like the GLTN's Costing of Land Administration Services (COFLAS) [72]. The cost components of the mobile app and the satellite imagery added up to an estimated cost of GH\&37 (EUR 9.25) per parcel (Table 3). The cost differences mostly stem from the limited use of professionals and the reliance on the local people and technologies readily available locally. The CLS also had an official smartphone, a Samsung Galaxy Note 3, which was used for the experiment. The mobile app however requires a license costing an annual subscription of at least $\mathrm{GH} \not 5600(€ 1400)$.

Table 3. Breakdown of the Cost of the Mapping Process.

\begin{tabular}{|c|c|c|c|}
\hline Activity & Cost/Wage & Quantity & Cost/Parcel \\
\hline Mapping (Workmanship) & GH $\not 40$ (EUR 10)/Day & 20 parcels/day & GHф 1 (EUR 0.25) \\
\hline Post-Processing & 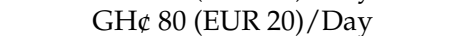 & 20 parcels/day & GH 4 (EUR 1) \\
\hline Printing of Satellite Image (A1) & GHф 40 (EUR 10)/Map & 2 Images & GHळ 0.17 (EUR 0.05) \\
\hline $\begin{array}{l}\text { Allocation Notes for each parcel } \\
\text { Equipment }\end{array}$ & $\mathrm{GH \not \subset} 4($ EUR 1$)$ & 1 Allocation Note & GHфॄ 4 (EUR 1) \\
\hline License for Mobile App & GHф 5600 (EUR 1400) for 230 parcels & 1 User & GHф 24.35 (EUR 6.07) \\
\hline Satellite Image & Free & 1 Strip & Free \\
\hline Smartphone & GHф 200 (EUR 200) & 1 Smartphone & GHф 3.48 (EUR 0.87) \\
\hline Total & & & GHæ3 36.83 (EUR 9.24) \\
\hline
\end{tabular}




\subsection{Participation}

The active participation of the local people was paramount in this experiment. Table 4 shows the process the experiment took as well as the role of the actors. The table shows the involvement of the researcher in five of the eleven steps of the experiment. All together the local people comprising the Traditional Authorities, the Customary Land Secretariat, the Farmers' Association, the Trusted Intermediaries and the local farmers undertook were involved in 10 out of the 11 steps (91\%), and undertook 6 out of the 11 steps (54\%) on their own (Table 4$)$. With respect to the accessibility and ease of use, 49 out of the 85 farmers had low-end smartphones and were familiar with the smart phone environment. Hence the process was mostly led by the local people. Furthermore, the involvement of the trusted intermediaries and the presence of neighbouring farmers created a layer of check for the boundary information collection. This showed the ability of the local people to replicate the process on their own since all the materials and equipment used were obtained from the local market.

Table 4. The Experiment Process and the Role of the Actors.

\begin{tabular}{|c|c|c|c|c|c|c|}
\hline Process of Experiment & & & Act & ors & & \\
\hline Step & TA & CLS & FA & Rs. & TI & Fm. \\
\hline Identify the land tenure arrangement in the area. & $\mathrm{x}$ & $\mathrm{x}$ & $\mathrm{x}$ & $\mathrm{x}$ & & \\
\hline Determine the farming arrangements in the area. & & $x$ & $x$ & $x$ & & \\
\hline Select Trusted Intermediaries. & $\mathrm{x}$ & $x$ & $x$ & & & \\
\hline Develop the process of mapping and recording of land rights & & $x$ & $x$ & & $\mathrm{x}$ & \\
\hline Train the Trusted Intermediaries. & & & & $\mathrm{x}$ & & \\
\hline Map and record land rights. & & & & & $x$ & $x$ \\
\hline Display mapped parcels. & & & & $x$ & $x$ & \\
\hline Authenticate the information collected. & & $x$ & $x$ & & $x$ & $x$ \\
\hline Train farmers and TI's in the use of satellite images. & & & & $x$ & & \\
\hline Identify farm parcels on satellite imagery. & & & $\mathrm{x}$ & & $x$ & $x$ \\
\hline Transfer information for allocation notes. & & $\mathrm{x}$ & & & & \\
\hline Percentage of Process & $18 \%$ & $54 \%$ & $54 \%$ & $45 \%$ & $45 \%$ & $27 \%$ \\
\hline
\end{tabular}

Actors-Traditional Authorities (TC), Customary Land Secretariat (CLS), Farmers' Association (FA), Researcher (Rs.), Trusted Intermediaries (TI), Farmers (Fm.).

\subsection{Attainability}

The approach took ten working days (Based on an 8-hour working day) to develop the process, execute it, process, and verify the information collected. This roughly translated to an average $20 \mathrm{~min}$ per parcel at the scale at which the experiment was executed, with the collection of the boundaries taking an average of $10 \mathrm{~min}$ per parcel. This may vary slightly depending on the scale of the experiment. However, the traditional approach in Ghana takes at least an hour for the boundaries of one parcel to collected. This experiment therefore proved faster than the traditional approach in Ghana.

In terms of the ability of the local people to replicate the process, this depended on the equipment used, and knowledge of the people. As already demonstrated under participation, the local people showed their initiative by being able to lead the process with influence from the researcher. Furthermore, equipment used were all locally available with the CLS. With their local knowledge of their surroundings, the use of their familiarity of smartphones, and the ease of accessing the equipment used, this approach is easily replicable in the area.

In summary, the results from the experiment showed that the approach is participatory, fast, incurs lower costs than the current approaches, and has the potential of being replicated by the local people. It is also capable of supporting the local land tenure system, though its accuracy is lower than the current approaches used. 


\section{Discussion}

This section provides a discussion of the outcome of the experiment, placing it in wider theoretical context of the aspects of participatory land administration identified in Section 2. Discussion is couched in terms of the key aspects of participatory land administration (c.f. Figure 1), that is, the technological innovation, local participation through citizen contribution, the local need for land consolidation in support of food security, and the institutional influence of professional standards and legal requirements (Government and Professionals).

\subsection{Technological Innovation Push: Mobile App vs. Satellite Images}

The experiment tested two technologies for collecting land information, satellite imagery and a mobile app, that are generally considered fast, cheap, and pro-poor by several studies $[7,8,13,68,73]$. However, whether these technologies are fit-for-purpose, is expected to depend on the context within which it is used [8]. The context in this experiment was food security in the Northern Ecological Zone of Ghana's customary lands. Most lands in this area are under the customary land tenure system, and fall within the customary land tenure system, together with a Sudan-savannah vegetation zone. The difference between this study and others that tested these technologies is that despite the lack of land tenure information in the areas within which they were tested, the approach was not compared to a pre-existing dataset to determine the validity and accuracy of the information collected. Though the use of satellite imagery is advocated for by Enemark et al. [8] and Lemmen and Zevenbergen [68] as an appropriate for pro-poor land administration, this experiment found that the mobile app provided a better approach. The use of the satellite imagery was limited in its ability to identify all the farm parcels in the area of interest: only $62 \%$ of the farm parcels in the area were identified on the satellite image. This is similar to the findings by [71] on the use of satellite imagery in the rainforest areas of Ghana. Previous studies in Kenya and Ethiopia that have used satellite imagery successfully were undertaken in mostly steppe and desert scrub vegetation zones allowing for more visibility of features to aid with the identification of the parcels with farmers walking their land parcels $[68,69,74]$. Aside from the inability of some farmers to identify their parcels, some of the parcels were also misplaced and the Trusted Intermediaries (TI) were unable to confirm these. This affects the support to the tenure security of the farmers as the unidentified farms may not end up in the land administration system. It also limits the ability to undertake land consolidation: some of the farms will be left out of the process. Furthermore, differences in the parcel shapes were found between the two methods. This would have a direct impact on the success of land consolidation as some land consolidation approaches rely on the shape of the parcels to determine the existence of land fragmentation and to regularize the parcel shape. Therefore, in terms of a fit-for-land consolidation and support to the tenure security, this study finds that the mobile app provides a result for the case location at hand.

In terms of the affordability and accessibility, there was a trade-off with accuracy. A core aim of this experiment was the ability of the local people to be able to replicate the process without external support. This led to the use of locally accessible tools as these lowered the costs incurred [7]. However, other studies such as Dyli et al. [70] and Molendijk et al. [19] who used a similar approach in their experiment, but added the Trimble R1 into the process, had a higher accuracy in their results, however at a significantly higher cost that would be unaffordable in the area of interest of this experiment. This notwithstanding, the costs of the experiment were also affected by the scale of the project at 230 parcels, which influenced significant cost components such as the licence for the mobile app, and the cost of the smartphone. Though the current cost of the experiment is closer to AfDB [75] estimate for the cost per parcel in Rwanda at $\$ 8$ (Table 3), the scaling up of the experiment (for example, tens of thousands of parcels rather than hundreds) is expected reduce these costs and put it far closer to Deininger et al.'s [76] \$1 per parcel recommendation for pro-poor land administration. 


\subsection{Bottom-Up Citizen Contribution: CLS, TIs and Quality Control}

The customary land administration set up in Ghana puts the allocation of customary lands in the hands of the local traditional authority, with the consequent land rights recordation and documentation in the hands of the governmental bodies [77]. However, advances by some customary land secretariats in the maintenance of update land rights registries show the potential of Customary Land Secretariats (CLS) as an alternative/informal land registry. These CLSs which are run by the local people, albeit mostly without formal training, are based on the local social and cultural customary practices. Mireku et al. [78] further demonstrates this with how some CLSs can regulate land registration in their area of jurisdiction with the use of allocation papers. However, these allocation papers lack supporting spatial information. The support of Participatory Land Administration (PLA) was found in the experiment as an effective approach to adding spatial information to the land records of the CLSs, as well as aiding in the effective allocation of lands.

Much like other studies conducted in crowdsourcing land information such as [13], it was found that the limited motivation of the local farmers to take part in the registration is linked to the cost of survey, and the long process of land registration. Furthermore, the farmers also saw the experiment as an opportunity to better ascertain the area of their farm parcels. On the part of the CLSs, this was an opportunity for them to be able to take an inventory of their lands based on their customary arrangements, taking the local needs into consideration. Though they lacked professional expertise, the CLS staff as TI's proved to be effective in the process as observed in Rwanda [8,44]. They were also highly respected by the community, being could manage the process together with the local people and ensuring that any dispute that arose during the use of the satellite images was quickly resolved without the involvement of the researcher. This is unlike other pilots where the researcher was a party in the process in order to regulate it, and pure crowdsourcing approaches where information is deemed correct where a lot of people agree with it $[43,71]$.

In summary, the local participation through TI's ensured a revered quality check on the citizens' contributions, with the CLS serving as a local land administration body to collect, manage, and disseminate land information.

\subsection{Societal Needs and Pull: Land Consolidation in Support of Food Security}

The main local needs in the area of interest are tenure security and food security. In the land administration domain, many existing innovative approaches support tenure security. A detailed record on land ownership, use rights, as well as the spatial extent of those rights is a condition sine qua non for land consolidation processes, but the success of land consolidation is dependent on the economic and ecological improvements for land and people [62]. PLA also allows for the inclusion and collection of other information relevant for land consolidation such as the types of crops that are grown on the farm parcels, as well as the crops that can potentially be grown, the topography of the area, the soil types, as well as the land values of the farm parcels [3,79]. However, information such as the topography, and soil types cannot be crowdsourced but need professional help in their identification and recording. This establishes the need for a partnership between the local people on one hand, and the government and professionals on the other hand to aid in the integration of the relevant information for land consolidation.

Recent approaches to land consolidation also largely favour a participatory approach to the planning and implementation [80,81]. This is to ensure that land consolidation is first demand driven, and secondly undertaken in a manner that fits the local conditions. PLA fits within these objectives as the active participation of the local people in the collection of land information builds their trust in the system and gives them confidence in the land management activities that will arise from it.

In summary, though a full land consolidation experiment was not undertaken, this first test of the PLA showed that it can incorporate land information relevant for land consolidation by involving the local people in the collection of land information. This experiment also showed how PLA is likely to 
make the local people feel a sense of ownership of the system that results and builds their trust in the land management activities for which it will be used.

\subsection{Top-Down Institutional Influence: Professional Standards and Legal Requirements}

In order for the innovative approach to fit into the formal system at a later time, it is necessary for it to fit into the current legal framework [44]. The legal framework provides the laws and regulations upon which authorities rely upon to determine land administration processes. In Ghana, the laws that cover the land administration processes include the Land Title Registration Laws of 1986 (PNDCL 152), the Land Registry Act of 1962 (Act 122), which deal with title and deed registration respectively, as well as the nature of registrable rights; the Survey Act of 1962 (Act 172) governs the land survey practice in the country. The Survey (Supervision and Approval of Plans) Regulations of 1989 (LI 1444) and the Technical Guidelines for Spatial Data Capture and Presentation in Ghana of 2008 set the standards for land surveying, for the purposes of conveyances, leases, assignment, charge, or transfer. However, these standards fall short of specifying the regulations for mapping customary rights and interests and the administration of customary lands outside the land registries. The customary lands are governed by the customs and traditions of the area by the Traditional authorities, usually through their CLSs [77,78]. The Land Title Registration law allows for the use of general boundaries in the first survey. This provides an opportunity to use innovative approaches in rural areas where a high accuracy is not a necessity. The authority of the CLSs drawn from the traditional authorities is empowered by the constitution. The CLSs can therefore legally keep a registry of lands outside the formal registry, although these have very little legal implications outside that particular traditional area [78].

In summary, it is seen that PLA is supported by the legal framework of Ghana because first, the general boundary concept used in supported by the land title registration law; secondly, the customary rights that will be recorded are supported by the laws, and thirdly, the process and the system will be managed by the Traditional Authority, through its CLS, which is mandated to manage customary lands.

\section{Conclusions}

This paper examined how participatory land administration fits into customary land administration to support responsible land consolidation. This was done by undertaking an experiment using two technologies, a smartphone app and a satellite image. The experiment was then evaluated in terms of reliability, affordability, participation and attainability. Though this experiment does not test the results on a land consolidation project, it evaluates the potential of its use on land consolidation projects. This first approach to use participatory land administration on customary lands shows that, theoretically, it can support the land tenure system, it is cheaper, and faster than the traditional approaches, and the technologies tested are easy to use by the community and supported by the local land administration structures. It is found to have the potential to support land consolidation, as it is able to collect the needed land information. However, this experiment did not undertake land consolidation to test this. Further studies are needed to understand how it can hold up when it is scaled up and applied in a land consolidation project.

The two technologies used, the mobile app and satellite image, have been recommended as fit for purpose approaches. However, in terms of reliability and attainability, the mobile app was found to be a more appropriate technology for capturing the farm boundaries in the area. This is because the smartphone app was found to be easy to use after the farmers received little training and all the farm parcels were captured using it. The use of the mobile app however needs more investigation in the context of customary lands. The satellite image was found to be more difficult and the identification of the farms was confusing for the farmers. Both were however affordable and faster than the traditional approaches. No major disputes were encountered that required the intervention of the traditional authorities, however, some confusion arose in the identification of the parcels on the satellite image. These disputes were settled by the farmers themselves. 
In terms of the participation, there was a general willingness to participate. The famers' involvement and contribution built up their trust in the system as they were involved in the building of the approach, and they collected the information themselves. The local land administration structure which had also started to build its local registry provided an adequate support for the for the approach as Participatory Land Administration (PLA) is capable of spatially supporting the allocation process of the Customary Land Secretariat (CLS), in anticipation of the land title registration of the area. In relation to the statutory requirements, although the PLA approaches meet the legal requirements of the set by the laws governing the registration of land, the professional regulations are not adequately met. However, the progress towards the registration of all customary interests eventually enable the integration of the data collection using this approach to the land title registry. It is therefore recommended that further investigation be conducted into how the various customary land rights can be integrated into the land title registry. Further research needs to be done in terms of how to scale up the approach to involve more than one customary land secretariat to further reduce the costs and provide a level of standardization.

With respect to the support for land consolidation, though this experiment did not undertake a full land consolidation, it was found to enable the capture of all customary land rights as well as other information relevant to land consolidation. Furthermore, the participatory nature of the process provides a stepping stone to the community's participation in land consolidation, further enabling a participatory approach to land consolidation. In developing a responsible land consolidation on customary lands, further research will be done on using the land information collected through PLA to aid with valuation of customary rural farm parcels as well as a land reallocation process.

Acknowledgments: The authors thank the DigitalGlobe Foundation for the providing the satellite imagery. The research work was sponsored by the University of Twente.

Author Contributions: Kwabena Asiama collected and prepared the data for this research article. Rohan Bennett and Jaap Zevenbergen contributed to and supervised the analysis and interpretation of the data. The manuscript was written by Kwabena Asiama, with contributions from Rohan Bennett and Jaap Zevenbergen.

Conflicts of Interest: The authors declare no conflict of interest.

\section{References}

1. Asiama, K.O.; Bennett, R.M.; Zevenbergen, J.A. Land Consolidation for Sub-Saharan Africa's Customary Lands-The Need for Responsible Approaches. Am. J. Rural Dev. 2017, 5, 39-45.

2. Bennett, R.; Rockson, G.; Haile, S.A.; Nasr, J. Groenendijk, Land Administration for Food Security. In Advances in Responsible Land Administration; Zevenbergen, J.A., de Vries, W.T., Bennett, R., Eds.; CRC: Boca Raton, FL, USA, 2015; pp. 37-52.

3. Lemmen, C.; Jansen, L.J.M.; Rosman, F. Informational and computational approaches to Land Consolidation. In Proceedings of the FIG Working Week 2012-Knowing to Anage the territory, Protect The Environment, Evaluate the Cultural Heritage, Rome, Italy, 6-10 May 2012.

4. United Nations Economic Commission for Europe (UNECE). Social and Economic Benefits of Good Land Administration; HM Land Registry: London, UK, 2005.

5. Asiama, K.O.; Bennett, R.M.; Zevenbergen, J.A. Land consolidation on Ghana's rural customary lands: drawing from The Dutch, Lithuanian and Rwandan Experiences. J. Rural Stud. Rev. 2017. submitted.

6. Habitat, U.N. Handling Land-Innovative Tools for Land Governance and Secure Tenure; UN-Habitat/ International Institute of Rural Reconstruction: Nairobi, Kenya, 2012.

7. Zevenbergen, J.A.; Augustinus, C.; Antonio, D.; Bennett, R.M. Pro-poor land administration: Principles for recording the land rights of the underrepresented. Land Use Policy 2013, 31, 595-604. [CrossRef]

8. Enemark, S.; Bell, K.C.; Lemmen, C.; McLaren, R. Fit for Purpose Land Administration; The World Bank and the International Federation of Surveyors: Copenhagen, Denmark, 2014.

9. De Vries, W.T.; Bennett, R.M.; Zevenbergen, J.A. Toward Responsible Land Administration. In Advances in Responsible Land Administration; Zevenbergen, J.A., Bennett, R.M., de Vries, W.T., Eds.; CRC: Boca Raton, FL, USA, 2015; pp. 3-14. 
10. Barry, M.; Augustinus, C. Property Theory, Metaphors and the Continuum of Land Rights; UN-Habitat: Nairobi, Kenya, 2015.

11. Zevenbergen, J.A.; Augustinus, C. Designing a pro poor land recordation system. In Proceedings of the FIG Working Week 2011: Bridging the Gap Between Cultures, Marrakech, Morocco, 18-22 May 2011.

12. Lemmen, C. The Social Tenure Domain Model: A Pro Poor Land Tool; International Federation of Surveyors: Copenhagen, Denmark, 2010.

13. Basiouka, S.; Potsiou, C. VGI in Cadastre: A Greek experiment to investigate the potential of crowd sourcing techniques in Cadastral Mapping. Surv. Rev. 2012, 44, 153-161. [CrossRef]

14. Crommelinck, S.; Bennett, R.; Gerke, M.; Nex, F.; Yang, M.; Vosselman, G. Review of Automatic Feature Extraction from High-Resolution Optical Sensor Data for UAV-Based Cadastral Mapping. Remote Sens. 2016, 8, 689. [CrossRef]

15. De Vries, W.T.; Bennett, R.M.; Zevenbergen, J.A. Neo-cadastres: Innovative solution for land users without state based land rights, or just reflections of institutional isomorphism? Surv. Rev. 2015, 47, 220-229. [CrossRef]

16. Mumbone, M.; Bennett, R.M.; Gerke, M.; Volkmann, W. Innovations in Boundary Mapping: Namibia, Customary Lands and UAVs. In Proceedings of the Linking Land Tenure and Use for Shared Properity, Washington, DC, USA, 23-27 March 2015.

17. Rahmatizadeh, S.; Rajabifard, A.; Kalantari, M. A conceptual framework for utilising VGI in land administration. Land Use Policy 2016, 56, 81-89. [CrossRef]

18. Basiouka, S.; Potsiou, C. The volunteered geographic information in cadastre: Perspectives and citizens' motivations over potential participation in mapping. GeoJournal 2014, 79, 343-355. [CrossRef]

19. Molendijk, M.; Morales, J.; Lemmen, C. Light Mobile Collection Tools for Land Administration. GIM Int. 2015. [CrossRef]

20. Williamson, I.P.; Enemark, S.; Wallace, J.; Rajabifard, A. Land Administration for Sustainable Development; ESRI: Redlands, CA, USA, 2010.

21. Asiama, K.O.; Bennett, R.; Zevenbergen, J.A. Participatory Land Administration: A New Vista towards Responsible Land Consolidation in Customary Lands? In Proceedings of the Joint Workshop FIG Commission 3 \& Commission 7: Crowdsourcing of Land Information, ST Julians, Malta, 16-20 November 2015.

22. Bennett, R.; Alemie, B.K. Fit-for-purpose land administration: Lessons from urban and rural Ethiopia. Surv. Rev. 2016, 48, 11-20. [CrossRef]

23. Arnstein, S. A Ladder of Citizen Participation. J. Am. Inst. Plann. 1969, 35, 216-224. [CrossRef]

24. Smith, B. Public Policy and Public Participation Engaging Citizens and Community in the Development of Public Policy; Health Canada: Ottawa, ON, Canada, 2003.

25. Asiama, K.O.; Lengoiboni, M.N.; van der Molen, P. Compulsory Land Acquisition and Resettlement on Customary Lands in Ghana-A Governance Perspective. In Proceedings of the LANDac International Conference on Land Governance for Equitable and Sustainable Development, Utrecht, The Netherlands, 8-10 July 2015.

26. Innes, J.E.; Booher, D.E. Reframing Public Participation: Strategies for the 21st Century. Plan. Theory Pract. 2004, 5, 419-436. [CrossRef]

27. Goodchild, M. Citizens as voluntary sensors: Spatial data infrastructure in the world of Web 2.0. Int. J. Spat. Data Infrastruct. Res. 2007, 2, 24-32.

28. Hudson-Smith, A.; Crooks, A.; Gibin, M.; Milton, R.; Batty, M. NeoGeography and Web 2.0: Concepts, tools and applications. J. Locat. Based Serv. 2009, 3, 118-145. [CrossRef]

29. Goodchild, M.F. Citizens as sensors: The world of volunteered geography. GeoJournal 2007, 69, $211-221$. [CrossRef]

30. Sui, D.Z. The wikification of GIS and its consequences: Or Angelina Jolie's new tattoo and the future of GIS. Comput. Environ. Urban Syst. 2008, 32, 1-5. [CrossRef]

31. See, L.; Mooney, P.; Foody, G.; Bastin, L.; Comber, A.; Estima, J.; Fritz, S.; Kerle, N.; Jiang, B.; Laakso, M.; et al. Crowdsourcing, Citizen Science or Volunteered Geographic Information? The Current State of Crowdsourced Geographic Information. ISPRS Int. J. Geo-Inform. 2016, 5, 55. [CrossRef]

32. Fast, V.; Rinner, C. A Systems Perspective on Volunteered Geographic Information. ISPRS Int. J. Geo-Inform. 2014, 3, 1278-1292. [CrossRef] 
33. Song, W.; Sun, G. The role of mobile volunteered geographic information in urban management. In Proceedings of the 2010 18th International Conference on Geoinformatics, Beijing, China, 18-20 June 2010; pp. 1-5.

34. Gómez-Barrón, J.-P.; Manso-Callejo, M.-Á.; Alcarria, R.; Iturrioz, T. Volunteered Geographic Information System Design: Project and Participation Guidelines. ISPRS Int. J. Geo-Inform. 2016, 5, 108. [CrossRef]

35. Turner, A. Introduction to Neogeography; O'Reilly Media: Sebastopol, CA, USA, 2006.

36. Geiger, D.; Schader, M. Personalized task recommendation in crowdsourcing information systems-Current state of the art. Decis. Support Syst. 2014, 65, 3-16. [CrossRef]

37. Poorazizi, M.; Hunter, A.; Steiniger, S. A Volunteered Geographic Information Framework to Enable Bottom-Up Disaster Management Platforms. ISPRS Int. J. Geo-Inform. 2015, 4, 1389-1422. [CrossRef]

38. Arsanjani, J.J.; Vaz, E. An assessment of a collaborative mapping approach for exploring land use patterns for several European metropolises. Int. J. Appl. Earth Obs. Geoinf. 2015, 35, 329-337. [CrossRef]

39. de Leeuw, J.; Said, M.; Ortegah, L.; Nagda, S.; Georgiadou, Y.; DeBlois, M. An Assessment of the Accuracy of Volunteered Road Map Production in Western Kenya. Remote Sens. 2011, 3, 247-256. [CrossRef]

40. Mahabir, R.; Stefanidis, A.; Croitoru, A.; Crooks, A.; Agouris, P. Authoritative and Volunteered Geographical Information in a Developing Country: A Comparative Case Study of Road Datasets in Nairobi, Kenya. ISPRS Int. J. Geo-Inform. 2017, 6, 24. [CrossRef]

41. Keenja, E.; de Vries, W.T.; Bennett, R.M.; Laarakker, P. Crowd Sourcing for Land Administration: Perceptions within Netherlands Kadaster. Available online: https:/ /www.fig.net/resources/proceedings / fig_proceedings/fig2012/papers/ts03b/TS03B_keenja_devries_et_al_5611.pdf (accessed on 16 May 2017).

42. McLaren, R. Crowdsourcing Support of Land Administration: A New, Collaborative Partnership between Citizens and Land Professionals; RICS: London, UK, 2011.

43. Navratil, G.; Frank, A.U. VGI for Land Administration. Available online: http://www.int-arch-photogrammremote-sens-spatial-inf-sci.net/XL-2-W1/159/2013/isprsarchives-XL-2-W1-159-2013.pdf (accessed on 16 May 2017).

44. McLaren, R. Engaging the Land Sector Gatekeepers in Crowsourced Land Administration. In Proceedings of the Conference on Land and Poverty, Washington, DC, USA, 8-11 April 2013.

45. Bishr, M.; Kuhn, W. Geospatial Information Bottom-Up: A Matter of Trust and Semantics. In The European Information Society; Fabrikant, S.I., Wachowicz, M., Eds.; Springer: Berlin/Heidelberg, Germany, 2007; pp. 365-387.

46. Siriba, D.N.; Dalyot, S. Adoption of volunteered geographic information into the formal land administration system in Kenya. Land Use Policy 2017, 63, 279-287. [CrossRef]

47. Schaefer, P.F.; Schaefer, C. An Innovative Approach to Land Registration in the Developing World Using Technology to Bypass the Bureaucracy. Available online: https:/ /www.cato.org/publications/policy-analysis/ innovative-approach-land-registration-developing-world-using-technology (accessed on 16 May 2017).

48. Peters, M.; Schneider, M.; Griesshaber, T.; Hoffmann, V.H. The impact of technology-push and demand-pull policies on technical change-Does the locus of policies matter? Res. Policy 2012, 41, 1296-1308. [CrossRef]

49. di Stefano, G.; Gambardella, A.; Verona, G. Technology push and demand pull perspectives in innovation studies: Current findings and future research directions. Res. Policy 2012, 41, 1283-1295. [CrossRef]

50. Ghawana, T.; Bennett, R.; Oliveira, J.; Zevenbergen, J.A.; Paixão, S.; Carneiro, A.F.T. Applying the Knowledge Innovation Value Chain Model to Land Administration Research. Available online: https://www.fig.net/resources/proceedings/fig_proceedings/fig2016/papers/ts06a/TS06A_ghawana_ bennett_et_al_7969_abs.pdf (accessed on 16 May 2017).

51. Crescenzi, R.; Rodríguez-Pose, A. Reconciling top-down and bottom-up development policies. Environ. Plan. A 2011, 43, 773-780. [CrossRef]

52. Enemark, S.; McLaren, R.; Lemmen, C. Fit-for-Purpose Land Administration—Guiding Principles for Country Implementation; UN-Habitat: Nairobi, Kenya, 2016.

53. Land Title Registration Law. Available online: http://thelandeconomist2007.synthasite.com/library/landtitle-registration-law-1986-pndcl-152- (accessed on 16 May 2017).

54. Asiama, S.O. Comparative Study of Land Administration Systems-Case Study of Ghana. Available online: http://www.ibrarian.net/navon/paper/COMPARATIVE_STUDY_OF_LAND_ADMINISTRATION_ SYSTEMS.pdf?paperid=1140240 (accessed on 16 May 2017). 
55. Ehwi, R.J.; Asante, L.A. Ex-Post Analysis of Land Title Registration in Ghana Since 2008 Merger. SAGE Open 2016, 6. [CrossRef]

56. MASDAR. Project Appraisal Document on a Proposed Credit to the Republic of Ghana for the Land Administration Project-2. Available online: http://documents.worldbank.org/curated/en/ 754421468257071446/pdf/583340PAD0P1201e0only1910BOX358312B.pdf (accessed on 16 May 2017).

57. Jones-Casey, K.; Knox, A. Ghana's Land Administration at a Crossroads. Available online: https: / / agriknowledge.org/downloads/0r9673801 (accessed on 16 May 2017).

58. Edmead, N. Open Title-A Low Cost Tool for Inventorying Property Rights—Experiences from Ghana. Available online: https://www.fig.net/resources/proceedings/fig_proceedings/fig2010/papers/fs04f/ fs04f_edmead_4037.pdf (accessed on 16 May 2017).

59. Landmapp. Landmapp: Unlocking Land Value-Ghana. 2016. Available online: http://www.landmapp. net/ghana/ (accessed on 25 January 2017).

60. Pickett, K. Landmapp—Land Solutions as a Scalable Business. Available online: http:/ /docs.wixstatic.com/ ugd/3208e6_0097871437734f04a42249c452f4ef39.pdf (accessed on 25 January 2017).

61. Kakraba-Ampeh, M.; Yeboah, E. Scaling Up Community Based Tools to Secure Land Rights. Available online: http:/ / rightsandresources.org/wp-content/uploads/RRI-Final-Report_v31.pdf (accessed on 16 May 2017).

62. Abubakari, Z.; van der Molen, P.; Bennett, R.; Kuusaana, E.D. Land consolidation, customary lands, and Ghana's Northern Savannah Ecological Zone: An evaluation of the possibilities and pitfalls. Land Use Policy 2016, 54, 386-398. [CrossRef]

63. Almirall, E.; Wareham, J. Living Labs: Arbiters of mid- and ground-level innovation. Technol. Anal. Strategy Manag. 2011, 23, 87-102. [CrossRef]

64. Liedtke, C.; Welfens, M.J.; Rohn, H.; Nordmann, J. LIVING LAB: User-driven innovation for sustainability. Int. J. Sustain. High. Educ. 2012, 13, 106-118. [CrossRef]

65. Pallot, M.; Trousse, B.; Senach, B.; Schaffers, H. Future internet and living lab research domain landscapes: Filling the gap between technology push and application pull in the context of smart cities. In Proceedings of the eChallenges e-2011 Conference Proceedings, IIMC International Information Management Corporation, Florence, Italy, 26-28 October 2011.

66. Byamugisha, F.F.K.; Burns, T.; Evtimov, V.; Santana, S.; Zulsdorf, G. Appraising Investments and Technologies for Surveying and Mapping for Land Administration in Sub-Saharan Africa; Report; World Bank: Washington, DC, USA, 2012.

67. Byamugisha, F. Securing Africa's Land for Shared Prosperity: A program to scale Up Reforms and Investments. Available online: http://documents.worldbank.org/curated/en/732661468191967924/pdf/ 780850PUB0EPI00LIC00pubdate05024013.pdf (accessed on 16 May 2017).

68. Lemmen, C.; Zevenbergen, J.A. First experiences with a high-resolution imagery-based adjudication approach in Ethiopia. In Innovations in Land Rights Recognition, Administration, and Governance; Deininger, $\mathrm{K}$., Augustinus, C., Enemark, S., Munro-Faure, P., Eds.; The World Bank: Washington, DC, USA, 2010; pp. 96-104.

69. Bennett, R.; Yimer, F.; Lemmen, C. Toward Fit-for-Purpose Land Consolidation. In Advances in Responsible Land Administration; CRC Press: Boca Raton, FL, USA, 2015; pp. 163-182.

70. Dyli, J.; Bennett, R.M.; Martinez, J.A. Apps for Land Administration: Exploring the Needs, Options and Future Developments. GIM Int. 2016, 30, 33-35.

71. Osei-Tutu, D.; Asante, L.A.; Appiah, M.N.; Bendzako, T.; Chigbu, U.E. Towards a Pro-Poor Customary Land Rights Security in Rural Ghana: Land Tenure Inventory Using Mobile Application by Local Youth. In Proceedings of the World Bank Conference on Land and Poverty, Washington, DC, USA, 15-17 March 2016.

72. Burns, T.; Haile, S.A. Costing and Financing of Land Administration Services (CoFLAS) in Developing Countries. Available online: http://www.gltn.net/index.php/land-tools/gltn-land-tools/costing-andfinancing-of-land-administration-services-coflas (accessed on 16 May 2017).

73. Kapitango, D.; Meijs, M. Land registration using aerial photography in Namibia: Costs and lessons. In Innovations in Land Rights Recognition, Administration, and Governance; Deininger, K., Augustinus, C., Enemark, S., Munro-Faure, P., Eds.; The World Bank: Washington, DC, USA, 2010; pp. 60-72.

74. Yimer, F. Fit-for-Purpose Land Consolidation: An Innovative Tool for Re-Allotment in Rural Ethiopia. Master's Thesis, University of Twente-ITC, Enschede, The Netherlands, 2014. 
75. AfDB. Land Tenure Regularization in Rwanda: Good Practices in Land Reform-Case Study. Available online: https://www.afdb.org/fileadmin/uploads/afdb/Documents/Publications/anrc/AfDB_ RwandaLandReform_FA.pdf (accessed on 16 May 2017).

76. Deininger, K.; Ali, D.A.; Holden, S.; Zevenbergen, J. Rural Land Certification in Ethiopia: Process, Initial Impact, and Implications for Other African Countries. World Dev. 2008, 36, 1786-1812. [CrossRef]

77. Biitir, S.B.; Nara, B.B. The role of Customary Land Secretariats in promoting good local land governance in Ghana. Land Use Policy 2016, 50, 528-536. [CrossRef]

78. Mireku, K.O.; Kuusaana, E.D.; Kidido, J.K. Legal implications of allocation papers in land transactions in Ghana-A case study of the Kumasi traditional area. Land Use Policy 2016, 50, 148-155. [CrossRef]

79. Sonnenberg, J. Fundamentals of Land Consolidation as an Instrument to Abolish Fragmentation of Agricultural Holdings. In Proceedings of the Land Consolidation: New Perspectives FIG XXII International Congress, Washington, DC, USA, 19-26 April 2002.

80. Louwsma, M.; van Beek, M.; Hoeve, B. A New Approach: Participatory Land Consolidation. Available online: https://www.fig.net/resources/proceedings/fig_proceedings/fig2014/papers/ts02d/TS02D_ louwsma_van_beek_et_al_7020.pdf (accessed on 16 May 2017).

81. Hartvigsen, M. Integrated Voluntary Land Consolidation-A Third Model for Land Consolidation and Land Banking in Central And Eastern Europe. Available online: http://www.fao.org/3/a-i5244tre.pdf (accessed on 16 May 2017).

(C) 2017 by the authors. Licensee MDPI, Basel, Switzerland. This article is an open access article distributed under the terms and conditions of the Creative Commons Attribution (CC BY) license (http://creativecommons.org/licenses/by/4.0/). 